\title{
In vitro surface temperature of nasal balloons during hot water inflation*
}

\author{
Carine A. Moene', Mats B-O. Hauge², Juha Silvola², Gregor Bachmann- \\ Harildstad $^{2}$ \\ ' Department of Otorhinolaryngology Akershus University Hospital, Nordbyhagen, Norway \\ 2 Department of Otorhinolaryngology Akershus University Hospital and Institute of Clinical Medicine, Campus Ahus, \\ University of Oslo, Nordbyhagen, Norway \\ ${ }^{3}$ Department of Ophthalmology Drammen Hospital, Vestre Viken, Drammen, Norway
}

Rhinology Online, Vol 2: $64-68,2019$

http://doi.org/10.4193/RHINOL/19.012

*Received for publication:

March 8, 2019

Accepted: April 10, 2019

Published: May 23, 2019

\begin{abstract}
Background: Posterior epistaxis is often treated with nasal packing by balloon compression or gauzes, and in refractory cases, with ligation of the sphenopalatine artery. These methods are painful, require admission and imply a substantial risk of complications. It has been shown that hot water irrigation is effective to stop bleeding. However, the hot water procedure is associated with patient discomfort, and temperatures over $52^{\circ} \mathrm{C}$ may cause tissue necrosis. The use of nasal balloons filled with hot water may potentially be equally effective and cause less discomfort, but has not yet been studied. The aim of this study was to determine the surface temperature of nasal balloons when filled with hot water.
\end{abstract}

Methodology: An in vitro study was performed to determine surface temperature of Epistat ${ }^{\oplus}$ and Rapid Rhino ${ }^{\circledR}$ nasal balloons when filled with water at different temperatures.

Results: There was a strong correlation between inserted water temperature and maximum temperature at Epistat ${ }^{\oplus}$ balloon surface. Maximum surface temperature occurred during the first 30 seconds after water insertion and there was a rapid temperature decline irrespective of inserted water temperature. There was a similar correlation for Rapid Rhino ${ }^{\oplus}$. However, surface temperatures were in general lower, maintained for a longer period and the peak temperature occurred later.

Conclusions: Hot water inflation in nasal balloons seems to be feasible and is unlikely to cause tissue necrosis with inserted water temperatures of $60^{\circ} \mathrm{C}$ or less.

Key words: epistaxis, hot water irrigation, nasal balloon

\section{Introduction}

Epistaxis is one of the most common reasons for emergency ear, nose and throat consultations and the risk is increased by several factors such as the use of anticoagulants and platelet inhibitors ${ }^{(1)}$. As the general population grows older, the use of such drugs and thereby the prevalence of epistaxis is expected to increase. Despite a generally good prognosis, epistaxis frequently causes hospitalization and, in some cases, even mortality ${ }^{(2)}$. Posterior bleeding, although less frequent, is usually more severe than anterior bleeding in the hospital setting. Nasal packing by balloon compression is considered first-line treat- ment prior to packing by gauzes ${ }^{(3)}$. However, these methods are painful, require admission and treatment time is significantly prolonged ${ }^{(4)}$ which leads to increased risk of complications. In fact, Melinte et al. recommended nasal packing only as a second-line treatment ${ }^{(5)}$.

Hence, there is need for better treatment strategies. Novoa et al. showed that hot water irrigation was superior to nasal packing in patients undergoing posterior epistaxis ${ }^{(6)}$. Furthermore, Ozmen et al. found in a randomized controlled trial of 120 children that $50^{\circ} \mathrm{C}$ saline solution was substantially better than room- 
temperature saline to obtain postadenoidectomy hemostasis

(7). This is in accordance with findings from two studies showing that hot saline irrigation during functional endoscopic sinus surgery reduced blood loss compared to irrigation with room temperature saline ${ }^{(8,9)}$.

Despite, the promising results from Novoa et al., there is still limited use of water irrigation in clinical practice. This is likely due to risk of aspiration, lack of patient cooperation and discomfort during the procedure. Potentially, balloon compression with hot water could provide the advantages from hot water irrigation with short duration of treatment and reduced risk for complications. As a temperature of $52^{\circ} \mathrm{C}$ or higher has been shown to induce necrosis of nasal mucosa ${ }^{(10)}$, it is important to know the balloon surface temperature after inflation with hot water. We have not found any data in the body of literature on surface temperature of nasal epistaxis balloons. To assess the possible risks and usability of hot water balloons in a clinical study, data on surface temperature are needed. The aim of the present study was to determine surface temperature of two types of nasal balloons used by our department, when filling them with water of different temperatures.

\section{Materials and methods}

We performed an in vitro study to determine surface temperature of Epistat ${ }^{\oplus}$ and Rapid Rhino ${ }^{\circledR}$ nasal balloons when filled with water at different temperatures. To imitate the situation in the nasal cavity, balloon surface measurements were performed in a heated water bath with a constant temperature of $37^{\circ} \mathrm{C}$ (Thermo Scientific SWB25, Typ 011-0847 Thermo Electron, Karlsruhe, Germany). The experiments were performed at Akershus University Hospital (altitude $162 \mathrm{~m}$ above sea level) in a room with a constant temperature of $22^{\circ} \mathrm{C}$.

To fill the balloons, we used water heated by a Sansaire Sous Vide (ModernChef Inc, China) (temperature range: $0-100^{\circ} \mathrm{C}$; accuracy $\pm 0.1^{\circ} \mathrm{C}$ ). Medical thermometers were used to control temperatures in the water bath, the water filled in the balloons and the surface temperature of the balloons (Durac ${ }^{\oplus}$ Digital Thermometer, VWR EU 620-0918. Accuracy $\pm 0.5^{\circ} \mathrm{C}$ ).

Syringes of $30 \mathrm{~cm}^{3}$ were filled with hot water heated by the Sous Vide and kept in the same water to maintain correct temperature. Thereafter, we filled the Epistat ${ }^{\oplus}$ anterior nasal balloons with $30 \mathrm{ml}$ hot water from the syringes. The balloons were filled over a period of 7-10 seconds. The procedure was repeated with gradually increased water temperatures from 57 to $65^{\circ} \mathrm{C}$ for filling the balloons.

To partly resemble pressure conditions in the nasal cavity, the temperature measurement was performed by pressing the
Table 1. Overview of Epistat ${ }^{\circledR}$ experiments.

\begin{tabular}{cccccc}
$\begin{array}{c}\text { Number } \\
\text { of obser- } \\
\text { vations }\end{array}$ & $\begin{array}{c}\text { Inserted } \\
\text { water } \\
\text { tempera- } \\
\text { ture }\left({ }^{\circ} \mathrm{C}\right)\end{array}$ & $\begin{array}{c}\text { Maxi- } \\
\text { mum } \\
\text { surface } \\
\text { tempera- } \\
\text { ture }\left({ }^{\circ} \mathrm{C}\right)\end{array}$ & $\begin{array}{c}\text { Surface } \\
\text { tempera- } \\
\text { ture30 s } \\
\left({ }^{\circ} \mathrm{C}\right)\end{array}$ & $\begin{array}{c}\text { Surface } \\
\text { tempera- } \\
\text { ture } 60 \mathrm{~s} \\
\left({ }^{\circ} \mathrm{C}\right)\end{array}$ & $\begin{array}{c}\text { Surface } \\
\text { tem- } \\
\text { perature } \\
120 \mathrm{~s} \\
\left({ }^{\circ} \mathrm{C}\right)\end{array}$ \\
\hline 6 & 57 & $47.6 \pm 0.8$ & $45.9 \pm 0.7$ & $44.5 \pm 0.3$ & $41.4 \pm 0.3$ \\
\hline 6 & 58 & $48.2 \pm 0.5$ & $46.3 \pm 0.9$ & $44.9 \pm 0.6$ & $41.7 \pm 0.6$ \\
\hline 5 & 59 & $50.2 \pm 0.2$ & $47.2 \pm 1.6$ & $44.8 \pm 2.0$ & $41.2 \pm 1.6$ \\
\hline 6 & 60 & $50.7 \pm 0.7$ & $49.2 \pm 0.8$ & $46.7 \pm 0.6$ & $42.5 \pm 0.6$ \\
\hline 7 & 61 & $50.8 \pm 1.1$ & $48.1 \pm 1.6$ & $45.9 \pm 0.9$ & $42.4 \pm 0.8$ \\
\hline 7 & 62 & $51.4 \pm 0.7$ & $48.9 \pm 1.5$ & $46.7 \pm 1.1$ & $43.1 \pm 1.5$ \\
\hline 7 & 63 & $51.4 \pm 1.2$ & $48.7 \pm 1.1$ & $46.3 \pm 1.2$ & $42.0 \pm 1.0$ \\
\hline 7 & 64 & $53.0 \pm 0.9$ & $51.5 \pm 0.6$ & $48.1 \pm 0.8$ & $43.1 \pm 0.6$ \\
\hline 6 & 65 & $53.4 \pm 1.0$ & $51.0 \pm 1.2$ & $46.8 \pm 1.5$ & $41.6 \pm 0.7$ \\
\hline
\end{tabular}

Values are given as mean \pm standard deviation.

thermometer electrode approximately $2 \mathrm{~mm}$ into the anterior balloon surface during hot water inflation. Maximum temperature within the first 30 seconds and the temperatures after 30, 60 and 120 seconds were recorded.

Furthermore, to see whether the relationship between water and surface temperature was different for coated balloons, we performed the same experiments with Rapid Rhino ${ }^{\circledR}$ balloons. In this case, the water temperature was gradually increased from 61 to $65^{\circ} \mathrm{C}$. A total of 17 Rapid Rhino ${ }^{\oplus}$ balloons were used.

\section{Statistical analysis}

Values are presented as mean \pm standard deviation (SD). To determine the relationship between surface and water temperature, we used linear regression and the Pearson correlation coefficient. A value of $\mathrm{p}<0.05$ was considered significant. GraphPad Prism version 7 was used for the analyses.

\section{Results}

Two Epistat ${ }^{\circledR}$ catheters were used for all experiments (filled and deflated 29 times each) without any obvious material damage. The surface texture of the coated Rapid Rhino ${ }^{\circledR}$ changes in contact with water and, therefore, we used a new balloon for each experiment $(n=17)$.

An overview of Epistat ${ }^{\circledR}$ and Rapid Rhino ${ }^{\circledR}$ surface measurements are given in Table 1 and 2, respectively. As illustrated in Figure 1, there was a strong correlation between inserted water temperature and maximum temperature at Epistat ${ }^{\oplus}$ balloon surface $(r=0.88, p<0.01)$. Furthermore, as shown in Figure 2, maximum surface temperature occurred during the first 30 seconds after water insertion and there was a rapid temperature decline irrespective of inserted water temperature. After $60 \mathrm{~s}$ all 


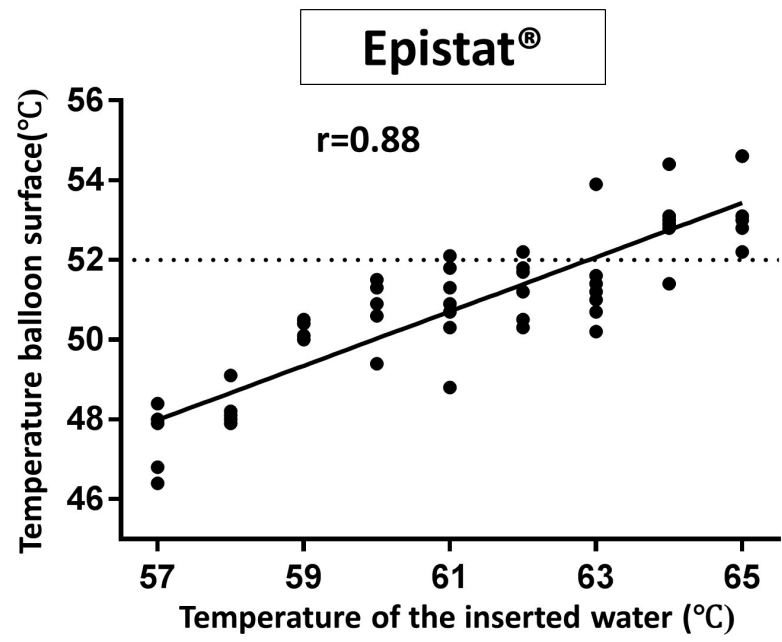

Figure 1. Water temperature versus maximum balloon surface temperature for Epistat ${ }^{\circledR}$. Please note that there is, as expected, a linear relationship between water temperature and maximum surface temperature. The dotted line indicates maximum surface temperature of $52^{\circ} \mathrm{C}$ which has been shown to be the threshold for necrosis of nasal mucosa.

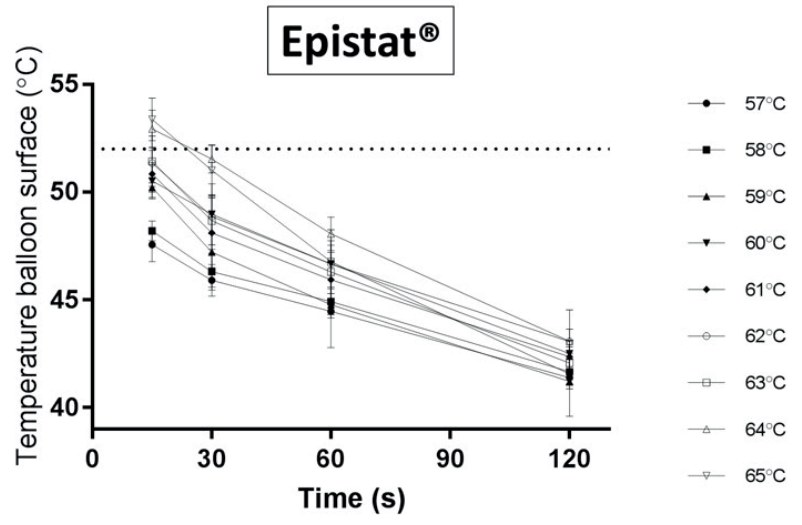

Figure 2. Balloon surface temperature as a function of time after hot water insertion (mean \pm SD). The different symbols indicate the different water temperatures at baseline. Please note how there is a rapid decline in balloon surface temperature. The dotted line indicates maximum surface temperature of $52^{\circ} \mathrm{C}$, which has been shown to be the threshold for necrosis of nasal mucosa.

measured surface temperatures were less than $50^{\circ} \mathrm{C}$.

There was a similar correlation between inserted water and maximum surface temperature for Rapid Rhino ${ }^{\circledast}(r=0.75, p<0.01)$ (Figure 3). However, surface temperatures were in general lower, maintained for a longer period, and the peak temperature occurred later.

\section{Discussion}

The present study demonstrates how surface temperature is strongly correlated, but consistently lower than inserted water

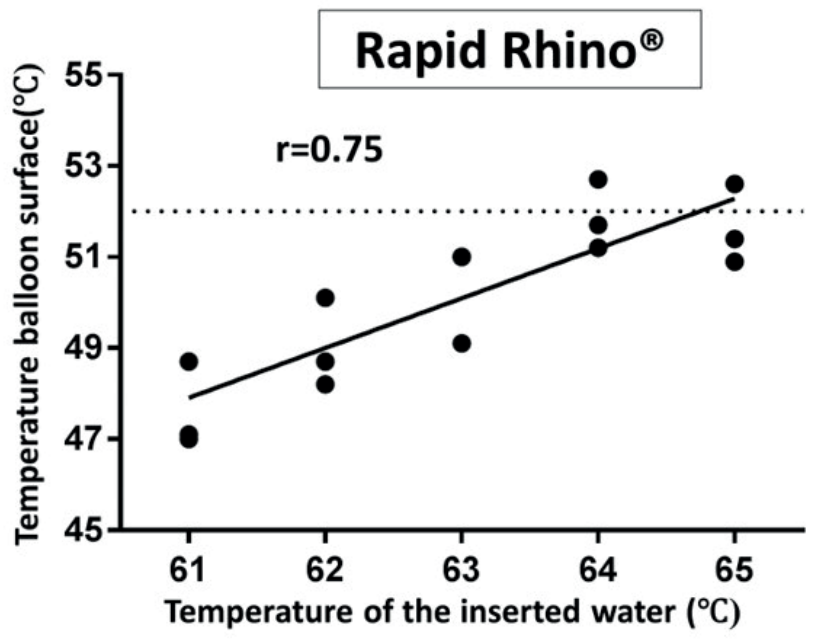

Figure 3. Water temperature versus maximum balloon surface temperature for Rapid Rhino ${ }^{\oplus}$. Please note that there is, as expected, a linear relationship between water temperature and maximum surface temperature. The dotted line indicates maximum surface temperature of $52^{\circ} \mathrm{C}$, which has been shown to be the threshold for necrosis of nasal mucosa.

temperature in Epistat ${ }^{\oplus}$ and Rapid Rhino ${ }^{\oplus}$ balloons. In Epistat ${ }^{\oplus}$ balloons, the threshold temperature of $52^{\circ} \mathrm{C}$ was not reached during any of the experiments with water temperatures $60^{\circ} \mathrm{C}$ below. Furthermore, for water temperatures of $59^{\circ} \mathrm{C}$ or less, maximum surface temperature of $52^{\circ} \mathrm{C}$ was consistently outside the $95 \%$ confidence interval. There was a rapid drop in temperature already during the first 60 seconds.

The haemostatic mechanisms of hot water irrigation are not fully understood. It has, however, previously been suggested that vasodilatation accompanied by oedema and thereby narrowing of the intranasal lumen may lead to pressure on the injured vessel and less bleeding. Furthermore, upregulation of the coagulation cascade and reduced intraluminal blood pressure due to mucosal vasodilatation may play a role ${ }^{(11,12)}$. Since it was previously shown that vasodilation and oedema of nasal mucosa occur at temperatures of $48^{\circ} \mathrm{C}$ or higher ${ }^{(10)}$, it is probably important to keep a temperature of at least $48^{\circ} \mathrm{C}$ for a significant period to obtain haemostasis. Hence, it seems reasonable to use the highest water temperature that does not cause mucosal necrosis.

The suggested threshold temperature of $52^{\circ} \mathrm{C}$ for mucosal tissue necrosis was derived from an experimental study in rabbits ${ }^{(10)}$. More recent human studies on hot water irrigation, have all used water temperatures of $50^{\circ} \mathrm{C}$ or less and tissue necrosis has not been reported ${ }^{(6,7,11-15)}$. Specifically, in the study from Schlegel-Wagner et al. patients were examined between 4 and 24 months after $50^{\circ} \mathrm{C}$ hot water irrigation for epistaxis without signs of mucosal injury ${ }^{(12)}$. Therefore, taking into account pre- 
Table 2. Overview of Rapid Rhino ${ }^{\circledR}$ experiments.

\begin{tabular}{cccccc}
$\begin{array}{c}\text { Number } \\
\text { of obser- } \\
\text { vations }\end{array}$ & $\begin{array}{c}\text { Inserted } \\
\text { water } \\
\text { tempera- } \\
\text { ture }\left({ }^{\circ} \mathrm{C}\right)\end{array}$ & $\begin{array}{c}\text { Maxi- } \\
\text { mum } \\
\text { surface } \\
\text { tempera- } \\
\text { ture }\left({ }^{\circ} \mathrm{C}\right)\end{array}$ & $\begin{array}{c}\text { Surface } \\
\text { tempera- } \\
\text { ture } 30 \mathrm{~s} \\
\left({ }^{\circ} \mathrm{C}\right)\end{array}$ & $\begin{array}{c}\text { Surface } \\
\text { tempera- } \\
\text { ture } 60 \mathrm{~s} \\
\left({ }^{\circ} \mathrm{C}\right)\end{array}$ & $\begin{array}{c}\text { Surface } \\
\text { tempera- } \\
\text { ture 120 }\end{array}$ \\
\hline 3 & 61 & $47.6 \pm 1.0$ & $47.0 \pm 1.0$ & $47.2 \pm 1.2$ & $44.8 \pm 1.0$ \\
\hline 3 & 62 & $49.0 \pm 1.0$ & $47.9 \pm 1.9$ & $48.0 \pm 0.2$ & $45.0 \pm 0.5$ \\
\hline 3 & 63 & $50.4 \pm 1.1$ & $48.4 \pm 0.8$ & $50.1 \pm 1.0$ & $46.3 \pm 0.1$ \\
\hline 3 & 64 & $51.9 \pm 0.8$ & $51.5 \pm 0.3$ & $50.7 \pm 0.5$ & $46.4 \pm 0.6$ \\
\hline 3 & 65 & $51.6 \pm 0.9$ & $50.7 \pm 0.7$ & $49.7 \pm 1.2$ & $46.1 \pm 0.5$ \\
\hline
\end{tabular}

Values are given as mean \pm standard deviation.

sent knowledge from clinical and experimental studies, mucosal temperatures up to $52^{\circ} \mathrm{C}$ are likely to be safe.

The observation that none of the Epistat ${ }^{\oplus}$ balloons ruptured despite numerous measurements suggest that it is safe to use them with hot water in patients.

Two of the reasons nasal hot water irrigation has not been used in clinical practice are patient discomfort and practical challenges with the procedure. The methodology used in the present study is feasible in clinical practice, and it is likely that there will be less patient discomfort with water-filled balloons compared to hot water irrigation.

Previous attempts to use hot water for haemostasis have not been limited to the nasopharynx. A small study of patients undergoing teeth extractions found that the extent of bleeding was reduced when applying gauze with hot water as compared to water with room temperature ${ }^{(16)}$.

\section{Limitations}

Despite using water bath of $37^{\circ} \mathrm{C}$ to resemble in vivo nasal conditions there are certainly other factors like for example pressure from the nasal cavity walls that could interfere with the speed of temperature decline. Maximum temperature, however, should not be affected.
The low number of Epistat ${ }^{\circledR}$ balloons used in the experiments means that hypothetical inter-balloon differences have not been measured.

\section{Conclusions}

Hot water inflation in Epistat ${ }^{\oplus}$ and RapidRhino ${ }^{\oplus}$ nasal balloons seems to be feasible and is unlikely to cause tissue necrosis with inserted water temperatures of $60^{\circ} \mathrm{C}$. Future studies should investigate whether such approach is effective for treatment of posterior epistaxis and whether it causes less patient discomfort than existing treatments.

\section{Acknowledgement}

The authors are grateful to Dr. Nicholas Barlow for proofreading the manuscript.

\section{Authorship contribution}

CAM: Collected and analyzed the data, wrote the manuscript: $\mathrm{MBH}$ : Collected the data, supervised the manuscript; JS: Important intellectual input, supervised the manuscript; GBH: Initiated data collection, important intellectual input, supervised statistics, co-writing and supervising the manuscript.

\section{Conflict of interest}

The authors report no conflicts.

\section{Ethics approval and consent to participate} Not applicable

\section{Consent for publication}

Not applicable

\section{Availability of data and materials}

Not applicable

\section{Funding}

No funding was used to support this study.

\section{References}

1. Seidel DU, Jacob L, Kostev K, Sesterhenn AM. Risk factors for epistaxis in patients followed in general practices in Germany. Rhinology. 2017:55(4):312-8.

2. Sauter TC, Hegazy K, Hautz WE, et al. Epistaxis in anticoagulated patients: Fewer hospital admissions and shorter hospital stays on rivaroxaban compared to phenprocoumon. Clin Otolaryngol. 2018;43(1):103-8.

3. Bequignon $E$, Verillaud $B$, Robard $L$, et al. Guidelines of the French Society of Otorhinolaryngology (SFORL). Firstline treatment of epistaxis in adults. Eur
Ann Otorhinolaryngol Head Neck Dis 2017:134(3):185-9.

4. Mehta N, Stevens K, Smith ME, et al. National prospective observational study of inpatient management of adults with epistaxis - a National Trainee Research Collaborative delivered investigation. Rhinology. 2019 Jan 5. doi: 10.4193/ Rhin18.239. [Epub ahead of print]

5. Melinte $V$, Musteata O, Sarafoleanu C. Epistaxis management - our point of view and literature review. Roman J Rhinol. 2017;7(28):207-13.

6. Novoa E, Schlegel-Wagner C. Hot water irrigation as treatment for intractable posterior epistaxis in an out-patient setting. Laryngol Otol. 2012;126(1):58-60.

7. Ozmen S, Ozmen OA. Hot saline irrigation for control of intraoperative bleeding in adenoidectomy: a randomized controlled trial. Otolaryngol Head Neck Surg. 2010;142(6):893-7.

8. Gan EC, Alsaleh S, Manji J, Habib AR, Amanian A, Javer AR. Hemostatic effect of hot saline irrigation during functional endoscopic sinus surgery: a randomized controlled trial. Int Forum Allergy Rhinol. 2014:4(11):877-84 
9. Shehata A, Ibrahim M, Abd-El-Fattah M Topical tranexamic acid versus hot saline for field quality during endoscopic sinus surgery. Egypt J Otolaryngol. 2014;30(4).

10. Stangerup SE, Thomsen HK. Histological changes in the nasal mucosa after hotwater irrigation. An animal experimental study. Rhinology. 1996;34(1):14-7.

11. Stangerup SE, Dommerby H, Siim C, Kemp $L$, Stage J. New modification of hot-water irrigation in the treatment of posterior epistaxis. Arch Otolaryngol Head Neck Surg. 1999;125(6):686-90.

12. Schlegel-Wagner C, Siekmann U, Linder T. Non-invasive treatment of intractable posterior epistaxis with hot-water irrigation. Rhinology. 2006;44(1):90-3.

13. Gan EC, Alsaleh S, Manji J, Habib AR,
Amanian A, Javer AR. Hemostatic effect of hot saline irrigation during functional endoscopic sinus surgery: a randomized controlled trial. Int Forum Allergy Rhinol. 2014;4(11):877-84.

14. Seidman MD. Hot-water irrigation in the treatment of posterior epistaxis. Arch Otolaryngol Head Neck Surg. 1999;125(11):1285.

15. Stangerup SE, Dommerby H, Lau T. Hotwater irrigation as a treatment of posterior epistaxis. Rhinology. 1996;34(1):18-20.

16. Haraji A, Rakhshan V, Hosseini V. Local heating of the wound with dressings soaked in saline at 42 degrees $C$ can reduce postoperative bleeding: a single-blind, split-mouth, randomised controlled clinical trial. Br J Oral Maxillofac Surg. 2016;54(3):266-9.
Gregor Bachmann-Harildstad, MD,

$\mathrm{PhD}$

Department of Otorhinolaryngology

Akershus University Hospital and

University of Oslo

Norway

Phone: + 4767964013

Fax: +4767964609

E-mail: gregor.bachmann-harildstad@medisin.uio.no

ISSN: 2589-5613 / O2019 The Author(s). This work is licensed under a Creative Commons Attribution 4.0 International License. The images or other third party material in this article are included in the article's Creative Commons license, unless indicated otherwise in the credit line; if the material is not included under the Creative Commons license, users will need to obtain permission from the license holder to reproduce the material. To view a copy of this license, visit http://creativecommons.org/ licenses/by/4.0/ 